\title{
Bartosz Siarka
}

Uniwersytet im. Adama Mickiewicza

Instytut Geografii Spoteczno-Ekonomicznej i Gospodarki Przestrzennej

bartosz.siarka@gmail.com

\section{Zróżnicowanie stopnia wykorzystania środków funduszy strukturalnych i Funduszu Spójności w realizacji zadań własnych gmin powiatu żnińskiego w latach 2004-2013 ${ }^{1}$}

\begin{abstract}
Zarys treści: Proces integracji z Unią Europejską umożliwił Polsce wkroczenie na nową ścieżkę rozwoju spoleczno-gospodarczego, a najważniejszym czynnikiem warunkującym ten rozwój stały się fundusze strukturalne oraz Fundusz Spójności. Niniejszy artykuł ma na celu określenie, w jakim stopniu gminy powiatu żnińskiego, stanowiące obszar badań, skorzystały ze środków europejskich w realizacji zadań własnych. Analiza obejmuje dwie perspektywy finansowe unijnej polityki regionalnej - 2004-2006 oraz 2007-2013 - a ponieważ drugi okres programowania z udziałem Polski niebawem zostanie zakończony, artykul ten stanowi doskonałą sposobność do podsumowania dotychczasowych rezultatów gmin powiatu żnińskiego w zakresie korzystania ze środków funduszy strukturalnych i Funduszu Spójności.
\end{abstract}

Słowa kluczowe: polityka regionalna, fundusze strukturalne, Fundusz Spójności, zadania własne, samorząd gminny

\section{Wprowadzenie}

Wstąpienie Polski do Unii Europejskiej z jednej strony stało się istotną szansą na przyspieszenie procesów rozwojowych w poszczególnych regionach naszego kraju, z drugiej jednak stanowi duże wyzwanie - w jaki sposób korzystać z nowych możliwości, by tej szansy nie zmarnować. Jednym z najważniejszych aspektów integracji z Unią Europejską jest dostęp do funduszy strukturalnych i Funduszu

1 Artykuł napisany na podstawie pracy magisterskiej pt. „Wpływ funduszy strukturalnych i Funduszu Spójności na realizację zadań własnych gmin powiatu żnińskiego" przygotowanej w Zakładzie Analizy Regionalnej IGSEiGP pod kierunkiem prof. UAM dr. hab. Pawła Churskiego. 
Spójności - nowych źródeł finansowania przedsięwzięć, zarówno infrastrukturalnych, jak i społecznych, w tym zadań własnych realizowanych przez jednostki samorządu terytorialnego (por. Churski 2008). Z uwagi na niski poziom akumulacji kapitału wewnętrznego charakterystyczny dla polskiej gospodarki, środki dostępne w ramach unijnej polityki regionalnej stały się istotnym instrumentem finansowania inwestycji rozwojowych w Polsce (por. Ładysz 2008). Zwiększyły one tym samym możliwości samorządu terytorialnego w zakresie realizacji zadań własnych. Dokonana w latach 90. szeroka decentralizacja zadań publicznych nie pociągnęła bowiem za sobą udostępnienia wystarczających źródeł finansowania (por. Izdebski 2011). Prowadziło to do pogłębiającego się zadłużania gmin, powiatów i województw, a tym samym zrodziło potrzebę poszukiwania bardziej efektywnego sposobu finansowania samorządu (por. Tetera 2001). Jednym z najważniejszych wyzwań, przed jakim stają obecnie polskie regiony, powiaty i gminy, jest pozyskanie i efektywne zagospodarowanie środków finansowych pochodzących z budżetu Unii Europejskiej. Należy podkreślić, że zróżnicowany stopień wykorzystania funduszy unijnych wynika z warunków, na jakich są one udostępniane, jak również z poziomu rozwoju społeczno-gospodarczego oraz przygotowania organizacyjnego i programowego poszczególnych jednostek samorządu terytorialnego (por. Ładysz 2008, Churski 2014).

Celem artykułu jest analiza zróżnicowania stopnia wykorzystania środków europejskich $\mathrm{w}$ realizacji zadań własnych gmin powiatu żnińskiego. Analiza ta dotyczy lat 2004-2013 i obejmuje dwie perspektywy finansowe polityki regionalnej Unii Europejskiej z udziałem Polski: 2004-2006, jako okres po uzyskaniu członkostwa, oraz 2007-2013, jako pierwszą perspektywę finansową, w której Polska uczestniczyła w całości jako pełnoprawny członek Unii Europejskiej. Aby ocenić, $w$ jakim stopniu gminy powiatu żnińskiego skorzystały $z$ możliwości współfinansowania zadań własnych ze środków europejskich, zarówno w całym okresie analizy, jak i w podziale na wyżej wymienione perspektywy finansowe, należy określić liczbę oraz wartość pozyskanych przez nie projektów unijnych. Ze względu na zakres niniejszego artykułu, obok liczby i wartości realizowanych $\mathrm{w}$ ramach polityki regionalnej przedsięwzięć, równie istotne jest ich ukierunkowanie, które jednak nie mogłoby zostać scharakteryzowane bez uprzedniej kategoryzacji zadań własnych samorządu lokalnego.

\section{Zadania własne samorządu gminnego i możliwości ich typologii}

Ustawa z dnia 8 marca 1990 r. o samorządzie gminnym ${ }^{2} w$ art. 7, ust. 1 wymienia $w$ dwudziestu punktach zadania własne samorządu gminnego. Wykaz ten, mimo że obszerny, nie jest jednak wyczerpujący. Jak bowiem podkreśla Borodo (2012), są to zadania przykładowo wymienione przez ustawę, natomiast szczegó-

Tj. Dz.U. z 2013 r. poz. 594 z późn. zm. 
łowe ustalenie zadań własnych samorządu gminnego zawierają dopiero ustawy, które regulują poszczególne dziedziny działalności gospodarczej lub społecznej. Tym bardziej zatem zasadne wydaje się stworzenie typologii zadań gminy. Do powstania wielu systematyzacji w tym zakresie przyczynili się Leoński (2006) i Niewiadomski (1998). Pierwszy uważał, że art. 7, ust. 1 ustawy o samorządzie gminnym ${ }^{3}$ ma na celu jedynie wskazanie pewnych ogólnych dyrektyw ustalających, jakie dziedziny należy zaliczyć do kategorii zadań własnych gminy. Leoński wyróżnił aż dziesięć takich dziedzin, przez co jego klasyfikacja stała się zbyt obszerna, by mogła być stosowana $w$ analizie stopnia wykorzystania środków unijnych w realizacji zadań własnych gminy (por. Leoński 2006). Niewiadomski (1998) natomiast, z uwagi na rozległość zadań samorządu terytorialnego i niemożność ich wyliczenia, poszukiwał ogólnej klasyfikacji lub też wyczerpującego zbioru poszczególnych rodzajów zadań. Efektem jego prac było stworzenie typologii, w której zadania własne samorządu gminnego zamykają się w czterech podstawowych kategoriach spraw: 1) infrastruktura techniczna, 2) infrastruktura społeczna, 3) porządek i bezpieczeństwo publiczne, 4) ład przestrzenny i ekologiczny. Powyższa klasyfikacja wydaje się odpowiednia do porównywania gmin w zakresie wykorzystania środków europejskich w realizacji zadań własnych, niemniej jednak pewne zadania wymienione $w$ art. 7 , ust. 1 ustawy o samorządzie gminnym ${ }^{4}$ mogą budzić wątpliwości, do której z czterech przedstawionych kategorii je zaliczyć. Zmierzając do klasyfikacji zadań własnych pozwalających na jej wykorzystanie do uporządkowania kierunków interwencji środków funduszy strukturalnych i Funduszu Spójności, bazując na systematyzacji Niewiadomskiego (1998), wydzielono pięć kategorii zadań własnych samorządu gminnego (patrz tab. 1):

1. infrastruktura techniczna i ład przestrzenny - należą do niej szczególnie drogi, przewody i urządzenia przesyłowe oraz działania poprawiające jakość przestrzeni publicznej;

2. usługi społeczne - do tej kategorii zalicza się aktywność samorządu w zakresie zaspokajania niematerialnych potrzeb społecznych;

3. infrastruktura społeczna - dotyczy wszelkich obiektów i urządzeń użyteczności publicznej;

4. porządek i bezpieczeństwo publiczne - zapewnienie odpowiedniego poziomu bezpieczeństwa ludności i mienia;

5. ład ekologiczny - zadania służące poprawie jakości środowiska, w tym właściwa gospodarka ściekowa (kanalizacja sanitarna i oczyszczanie ścieków) jako ten element infrastruktury technicznej, który w największym stopniu przyczynia się do poprawy stanu środowiska.

Przedstawiona autorska systematyzacja zadań wydaje się kompletna. Każde zadanie publiczne nakładane na gminę daje się przypisać do jednej z pięciu kategorii (patrz tab. 1), a poza tym klasyfikacja ta nie jest skomplikowana ani obszerna, co z kolei zapewnia łatwość stosowania. $Z$ tego względu typologia ta posłuży

\footnotetext{
3 Ibidem.

4 Ibidem.
} 
Tabela 1. Klasyfikacja zadań własnych samorządu gminnego

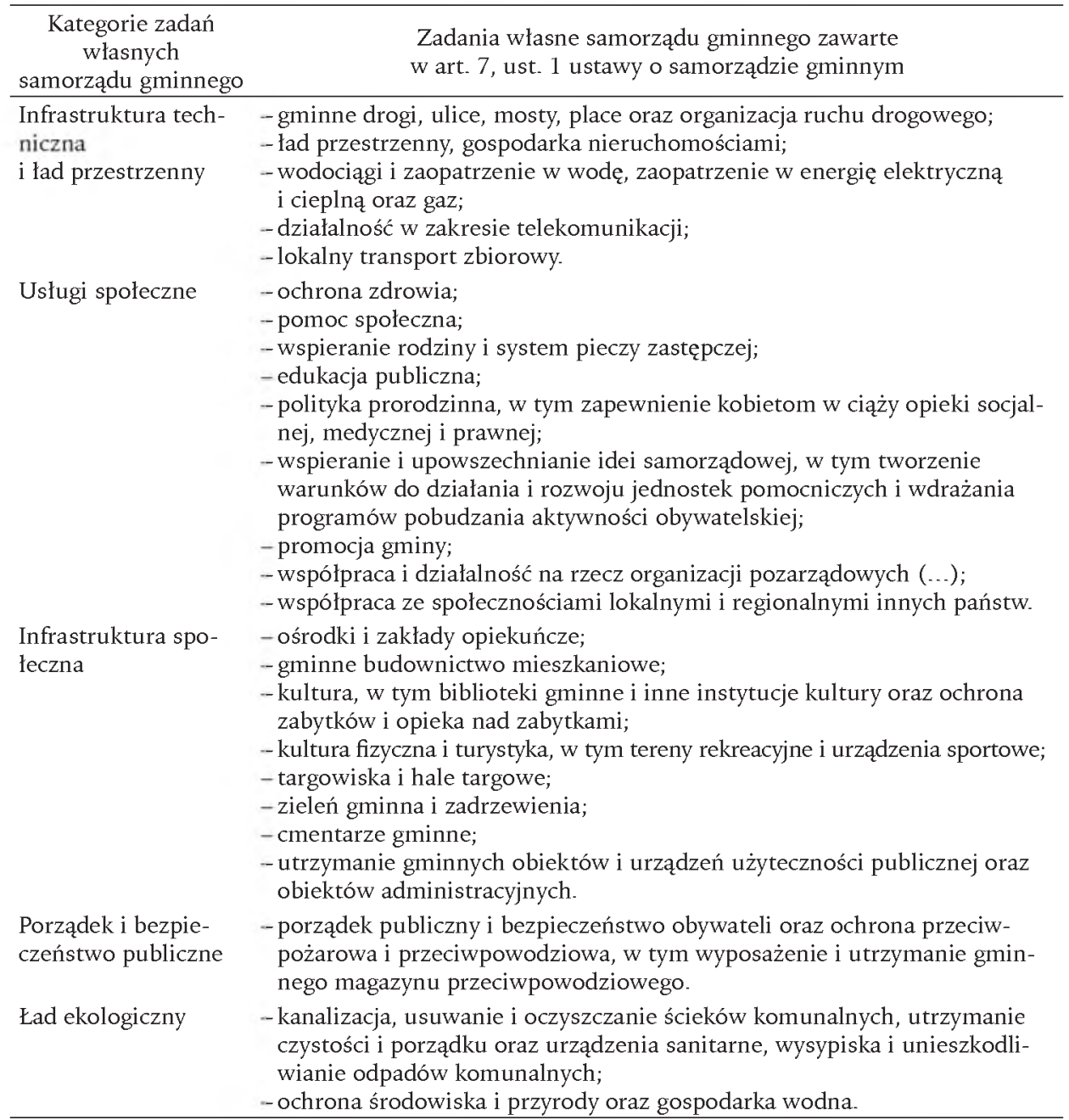

Źródlo: opracowanie własne.

w dalszej części artykułu do analizy kierunków projektów unijnych realizowanych przez gminy powiatu żnińskiego. 


\section{Zasady dostępu do środków europejskich}

W celu pozyskania środków unijnych na realizację projektu wniosek złożony przez beneficjenta zostaje poddany ocenie ${ }^{5}$. Procedura ta dzieli się na dwa etapy. W fazie pierwszej dokonuje się weryfikacji wniosków pod względem terminowości ich złożenia oraz zgodności formalnej. Wniosek niekompletny lub zawierający błędy może zostać odrzucony albo skierowany do jednokrotnej poprawy. Po spełnieniu wszystkich kryteriów formalnych wniosek o dofinansowanie zostaje natomiast zakwalifikowany do oceny merytorycznej. Na tym etapie sprawdzana jest jego treść, a ocenie podlegają między innymi dopuszczalność merytoryczno-techniczna projektu oraz jego jakość i wpływ założonych rezultatów projektu na realizację celów programu operacyjnego, w ramach którego beneficjent ubiega się o dofinansowanie. W tej fazie poszczególne kryteria podlegają ocenie punktowej, a wynikiem oceny merytorycznej jest uszeregowanie wniosków na podstawie liczby zdobytych punktów, odzwierciedlających stopień spełniania kryteriów. W ten sposób tworzona jest lista rankingowa projektów kwalifikujących się do uzyskania wsparcia ze środków unijnych, na podstawie której instytucja zarządzająca danym programem operacyjnym podejmuje decyzję o dofinansowaniu projektów, biorąc pod uwagę liczbę zdobytych punktów oraz wysokość alokacji na dany konkurs (por. System oceny projektów... 2010). Zgodnie z art. 30 ustawy z dnia 6 grudnia 2006 r. o zasadach prowadzenia polityki rozwoju ${ }^{6}$ podstawę uzyskania pomocy finansowej z budżetu Unii Europejskiej stanowi umowa o dofinansowanie projektu zawarta $z$ beneficjentem przez instytucję zarządzającą albo działającą w jej imieniu instytucję pośredniczącą lub wdrażającą. Umowa ta określa warunki pozyskania środków unijnych oraz prawa i obowiązki beneficjenta $z$ tym związane. Jest ona zawierana $w$ odniesieniu do projektu, który pozytywnie przeszedł wszystkie etapy oceny i został zakwalifikowany do uzyskania wsparcia ze środków funduszy europejskich, a dofinansowanie jest możliwe w ramach dostępnej alokacji na realizację poszczególnych działań i priorytetów w ramach programu operacyjnego. W sytuacji, gdy beneficjentem jest instytucja zarządzająca lub instytucja pośrednicząca, podstawę uzyskania unijnej pomocy finansowej może stanowić, poza umową o dofinansowanie, także decyzja podjęta przez instytucję zarządzającą lub pośredniczącą.

\section{Charakterystyka stopnia wykorzystania środków europejskich przez gminy powiatu żnińskiego}

Miernikiem stopnia wykorzystania środków unijnych w realizacji zadań własnych samorządu gminnego jest liczba oraz wartość projektów, które przeszły

Procedura ta nie dotyczy projektów indywidualnych oraz systemowych, o których mowa w art. 28 ust. 1 ustawy z dnia 6 grudnia 2006 r. o zasadach prowadzenia polityki rozwoju (tj. Dz.U. z 2009 r. nr 84, poz. 712 z późn. zm.).

$6 \quad$ Tj. Dz.U. z 2009 r. nr 84, poz. 712 z późn. zm. 


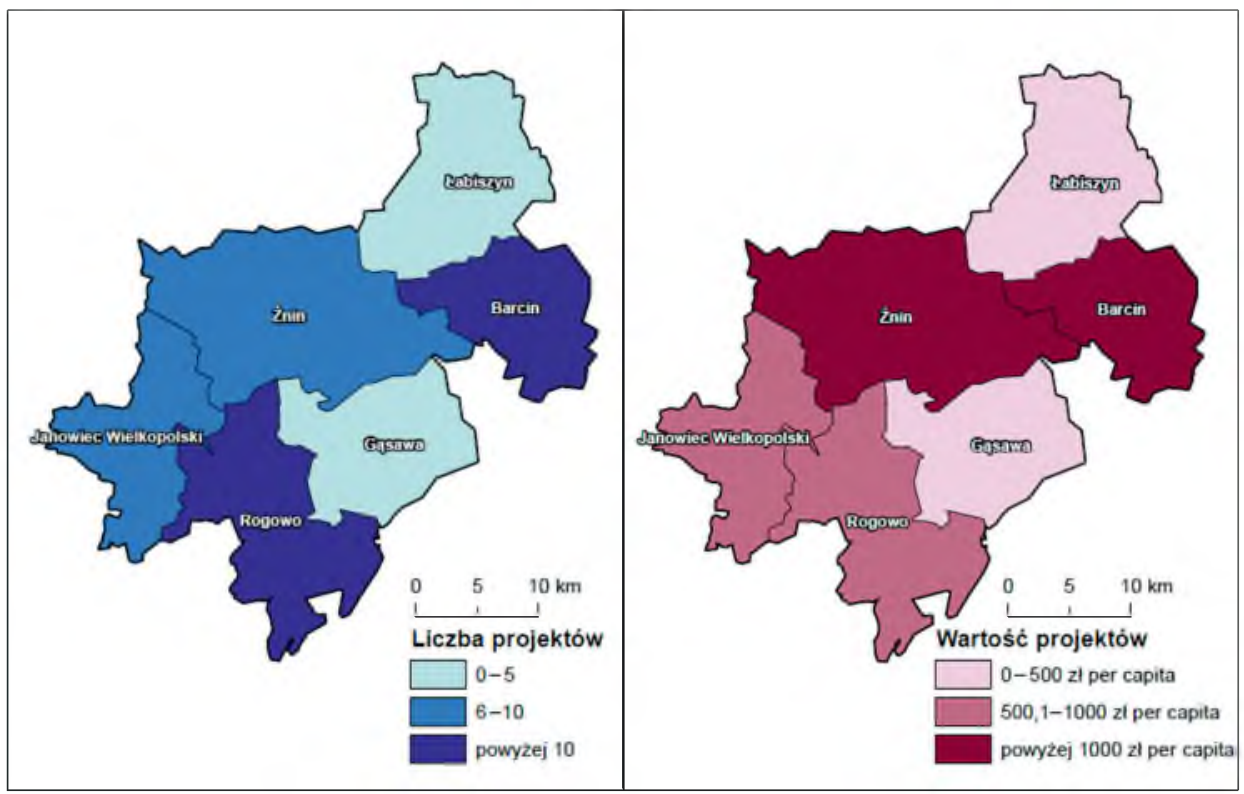

Ryc. 1. Stopień wykorzystania środków funduszy strukturalnych i Funduszu Spójności przez gminy powiatu żnińskiego w latach 2004-2013

Źródło: opracowanie własne na podstawie danych związanych z wykorzystaniem funduszy europejskich w Polsce (http://www.mapadotacji.gov.pl/; dostęp: 8.12.2014).

pozytywnie etap oceny formalnej i merytorycznej, a następnie uzyskały wsparcie w ramach jednego $z$ dostępnych $w$ danej perspektywie finansowej programów operacyjnych. W latach 2004-2013 gminy powiatu żnińskiego zrealizowały 58 projektów o łącznej wartości przekraczającej 76,5 mln zł (co daje 1081,2 zł na mieszkańca), uzyskując dofinansowanie ze środków funduszy strukturalnych i Funduszu Spójności na poziomie 56\% ${ }^{7}$. Na wynik ten w największym stopniu wpłynęła aktywność gmin Barcin i Żnin, które zrealizowały projekty warte w sumie 57,6 mln zł (75\% całkowitej wartości inwestycji wykonanych przez wszystkie gminy w powiecie), pozyskując w ramach polityki spójności Unii Europejskiej

\footnotetext{
Lata 2004-2013 rozumiane są tu jako okres obejmujący dwie perspektywy finansowe polityki regionalnej Unii Europejskiej: 2004-2006 oraz 2007-2013, a dane dotyczące liczby i wartości projektów realizowanych z udzialem środków funduszy strukturalnych i Funduszu Spójności są zgodne ze stanem na dzień 8 grudnia 2014 r. Część przedstawionych projektów wciąż znajduje się w fazie realizacji, czego przykładem jest wdrażany przez gminy Janowiec Wielkopolski i Rogowo projekt: „Rekultywacja składowisk odpadów w województwie kujawsko-pomorskim na cele przyrodnicze", w którego przypadku podpisanie umów o dofinansowanie nastąpilo 24 marca 2014 r. Mimo to projekt ten realizowany jest w ramach Programu Operacyjnego Infrastruktura i Środowisko na lata 2007-2013, gdyż zgodnie z zasadą automatycznego anulowania zobowiązań (zasadą $\mathrm{n}+2$ ), środki przyznane Polsce na rok 2013 można wydatkować do końca 2015 r. (por. art. 93, ust. 1 Rozporządzenia Rady (WE) nr 1083/2006 z dnia 11 lipca 2006 r. ustanawiającego przepisy ogólne dotyczące Europejskiego Funduszu Rozwoju Regionalnego, Europejskiego Funduszu Społecznego oraz Funduszu Spójności i uchylającego rozporządzenie (WE) nr 1260/1999. Dziennik Urzędowy Unii Europejskiej, L 210, 31.7.2006, wersja skonsolidowana).
} 
kwotę 29,3 mln zł (69\% środków unijnych pozyskanych przez gminy powiatu żnińskiego). W obu jednostkach nominalne wartości zrealizowanych przedsięwzięć były zbliżone, jednak w zakresie liczby wdrażanych projektów i ich wartości per capita (patrz ryc. 1) zdecydowanie wyższym stopniem wykorzystania środków w ramach polityki regionalnej wykazała się gmina Barcin (19 inwestycji w wysokości 1944,3 zł na osobę, przy 9 projektach w gminie Żnin wartych 1163,3 zł w przeliczeniu na mieszkańca). Również pod względem poziomu uzyskanego dofinansowania z funduszy europejskich gmina Barcin (55\%) przewyższyła gminę Żnin (47\%). Spośród pozostałych jednostek samorządu lokalnego w powiecie żnińskim, stosunkowo wysoką skutecznością w zakresie liczby przedsięwzięć realizowanych $z$ udziałem środków unijnych odznaczało się Rogowo (15 projektów $z$ dofinansowaniem na poziomie $71 \%$ ), jednak wartość tych inwestycji w przeliczeniu na mieszkańca $(872,3$ zl) należy uznać za przeciętną. Podobny wynik uzyskała gmina Janowiec Wielkopolski, w której koszt zrealizowanych projektów per capita wyniósł 868,1 zł, a udział środków europejskich przeznaczonych na wspólfinansowanie tych przedsięwzięć był identyczny, jak w przypadku Rogowa (71\%). Jedyna większa różnica pomiędzy obiema jednostkami dotyczyła liczby projektów - Janowiec Wielkopolski pozyskał ich o pięć mniej. Pozostałe dwie gminy powiatu żnińskiego - Łabiszyn i Gąsawa - zdecydowanie odbiegały od reszty samorządów lokalnych zarówno pod kątem liczby (odpowiednio jeden i cztery projekty), jak i wartości przedsięwzięć $z$ udziałem funduszy unijnych per capita (odpowiednio $338,4 \mathrm{zl}$, $\mathrm{z}$ dofinansowaniem na poziomie $62 \%$, oraz 285,8 zł, z 75-procentowym udziałem środków europejskich).

W pierwszej perspektywie finansowej polityki regionalnej z udziałem Polski, tj. w latach 2004-2006, spośród gmin powiatu żnińskiego jedynie Łabiszyn nie uzyskał wsparcia $z$ unijnego budżetu. Całkowita wartość 21 projektów zrealizowanych przez pozostałe jednostki samorządu lokalnego wyniosła natomiast 11,8 mln zł (166,5 zł per capita), z czego 70\% środków pochodziło z funduszy strukturalnych (patrz tab. 2). Klasyfikacja gmin pod względem stopnia wykorzystania dofinansowania $w$ ramach polityki regionalnej przedstawiała się jednak inaczej niż w całym okresie 2004-2013. Liderem w pierwszej perspektywie okazało się bowiem Rogowo, które zrealizowało aż 10 projektów o wartości 354,0 zł na osobę, pozyskując z budżetu Unii Europejskiej 70\% środków. Stosunkowo wysoką skuteczność wykazała także gmina Janowiec Wielkopolski, wdrażając pięć inwestycji wartych 282,4 zl per capita i uzyskując 62-procentowe dofinansowanie $\mathrm{w}$ ramach funduszy europejskich. W pierwszym okresie programowania niskim poziomem wykorzystania środków zewnętrznych odznaczały się natomiast gminy Żnin i Barcin. Pierwsza zrealizowała zaledwie jedno przedsięwzięcie w wysokości 221,9 zł na mieszkańca, z czego $74 \%$ środków pochodziło z unijnego budżetu. W Barcinie z kolei całkowita wartość wykonanych inwestycji, mimo pozyskania czterech projektów, wyniosła zaledwie 84,3 zl per capita, w tym $66 \%$ środków stanowiły fundusze europejskie. Jeszcze niższy stopień wykorzystania wsparcia unijnego wykazała ostatnia z gmin - Gąsawa - realizując jedno przedsięwzięcie o wartości 4,4 zł w przeliczeniu na osobę, $\mathrm{z}$ dofinansowaniem na poziomie $68 \%$. 
Tabela 2. Projekty wspóffinansowane ze środków funduszy strukturalnych i Funduszu Spójności pozyskane przez gminy powiatu żnińskiego w perspektywie 2004-2006

\begin{tabular}{|c|c|c|c|c|c|c|c|}
\hline Gmina & Lp. & Tytuł projektu & Wartość & UŚU & $\mathrm{PO}$ & Fundusz & KZW \\
\hline \multirow[t]{12}{*}{ Rogowo } & 1 & $\begin{array}{l}\text { Przebudowa drogi gminnej w obrębie placu Powstańców Wiel- } \\
\text { kopolskich w Rogowie }\end{array}$ & $504782,7 \mathrm{zl}$ & $60 \%$ & ZPORR & EFRR & \multirow{5}{*}{$\begin{array}{l}\text { Infrastruktura } \\
\text { techniczna i lac } \\
\text { przestrzenny }\end{array}$} \\
\hline & 2 & $\begin{array}{l}\text { Odbudowa drogi gminnej Rogowo-Gostomka w ciągu ul. } \\
\text { Sk tadowej }\end{array}$ & $389777,8 \mathrm{zl}$ & $75 \%$ & ZPORR & EFRR & \\
\hline & 3 & $\begin{array}{l}\text { Przebudowa drogi gminnej w Rogowie } \\
\text { w ciągu ul. Spółdzielczej }\end{array}$ & $260138,7 \mathrm{zl}$ & $60 \%$ & ZPORR & EFRR & \\
\hline & 4 & $\begin{array}{l}\text { Odbudowa drogi gminnej Rogowo-Eaziska w ciągu ul. 600-le- } \\
\text { cia }\end{array}$ & $207033,9 \mathrm{zl}$ & $75 \%$ & ZPORR & EFRR & \\
\hline & 5 & $\begin{array}{l}\text { Ukształtowanie centrum wsi Rogowo - urządzenie terenów } \\
\text { zieleni i przebudowa nawierzchni chodników }\end{array}$ & $191062,4 \mathrm{zl}$ & $80 \%$ & SPO-ROL & EFOiGR & \\
\hline & 6 & $\begin{array}{l}\text { Nowe kwalifikacje zawodowe dla rolników i domowników } \\
\text { szansą na rozwój wsi }\end{array}$ & $496931,2 \mathrm{zl}$ & $71 \%$ & ZPORR & EFRR & \multirow[t]{4}{*}{$\begin{array}{l}\text { Usługi spo- } \\
\text { leczne }\end{array}$} \\
\hline & 7 & Pracujący uczą się języków obcych & $177969,3 \mathrm{zl}$ & $75 \%$ & ZPORR & EFRR & \\
\hline & 8 & $\begin{array}{l}\text { Szkolenie komputerowe w Rogowie } \\
\text { dla osób pracujących }\end{array}$ & $86246,9 \mathrm{zl}$ & $75 \%$ & ZPORR & EFRR & \\
\hline & 9 & $\begin{array}{l}\text { Szkolenia językowe w Rogowie } \\
\text { dla dorosłych osób pracujących }\end{array}$ & $71090,6 \mathrm{zl}$ & $75 \%$ & ZPORR & EFRR & \\
\hline & 10 & $\begin{array}{l}\text { Modernizacja świetlic wiejskich w miejscowościach Ryszewo } \\
\text { i Budzislaw }\end{array}$ & $68874,2 \mathrm{zl}$ & $78 \%$ & SPO-ROL & EFOiGR & $\begin{array}{l}\text { Infrastruktura } \\
\text { spoleczna }\end{array}$ \\
\hline & \multicolumn{2}{|r|}{ Razem } & $2453907,6 \mathrm{zl}$ & \multirow{2}{*}{$70 \%$} & & & \\
\hline & \multicolumn{2}{|c|}{ Razem per capita } & $354,0 \mathrm{zl}$ & & & & \\
\hline \multirow[t]{3}{*}{$\begin{array}{l}\text { Janowiec } \\
\text { Wielkopolski }\end{array}$} & 1 & $\begin{array}{l}\text { Modernizacja drogi gminnej-- } \\
\text { ul. Łąkowa i Klemensa Janickiego } \\
\text { w Janowcu Wielkopolskim }\end{array}$ & $676544,3 \mathrm{zl}$ & $75 \%$ & ZPORR & EFRR & \multirow[t]{3}{*}{$\begin{array}{l}\text { Infrastruktura } \\
\text { techniczna i lad } \\
\text { przestrzenny }\end{array}$} \\
\hline & 2 & $\begin{array}{l}\text { Przebudowa ul. J. Słowackiego } \\
\text { w Janowcu Wielkopolskim }\end{array}$ & $655073,8 \mathrm{zl}$ & $60 \%$ & ZPORR & EFRR & \\
\hline & 3 & $\begin{array}{l}\text { Przebudowa ul. Orzeszkowej } \\
\text { w Janowcu Wielkopolskim }\end{array}$ & $557865,0 \mathrm{zl}$ & $60 \%$ & ZPORR & EFRR & \\
\hline
\end{tabular}




\begin{tabular}{|c|c|c|c|c|c|c|c|}
\hline Gmina & Lp. & Tytuł projektu & Wartość & UŚU & $\mathrm{PO}$ & Fundusz & KZW \\
\hline \multirow[t]{4}{*}{$\begin{array}{l}\text { Janowiec } \\
\text { Wielkopolski }\end{array}$} & 4 & $\begin{array}{l}\text { Budowa kanalizacji sanitarnej z przepompownią ścieków } \\
\text { Flantrowo-Janowiec Wlkp. }\end{array}$ & $636088,3 \mathrm{zł}$ & $50 \%$ & ZPORR & EFRR & Ład ekologiczny \\
\hline & 5 & $\begin{array}{l}\text { Remont świetlic i urządzenie placu rekreacyjno-sportowego na } \\
\text { terenie gminy Janowiec Wlkp. }\end{array}$ & $88443,9 \mathrm{zl}$ & $72 \%$ & SPO-ROL & EFOiGR & $\begin{array}{l}\text { Infrastruktura } \\
\text { społeczna }\end{array}$ \\
\hline & \multicolumn{2}{|r|}{ Razem } & $2614015,3 \mathrm{zl}$ & & & & \\
\hline & \multicolumn{2}{|c|}{ Razem per capita } & $282,4 \mathrm{zl}$ & $62 \%$ & & & \\
\hline \multirow[t]{3}{*}{ Żnin } & 1 & Ochrona zlewni rzeki Gąsawki - etap I & $5436001,9 \mathrm{zl}$ & $74 \%$ & ZPORR & EFRR & Ład ekologiczny \\
\hline & \multicolumn{2}{|c|}{ Razem } & $5436001,9 \mathrm{zl}$ & & & & \\
\hline & \multicolumn{2}{|c|}{ Razem per capita } & $221,9 \mathrm{zl}$ & $74 \%$ & & & \\
\hline \multirow[t]{6}{*}{ Barcin } & 1 & $\begin{array}{l}\text { Reintegracja zawodowa i spoleczna w Centrum Integracji } \\
\text { Spolecznej w Barcinie }\end{array}$ & $644016,9 \mathrm{zl}$ & $72 \%$ & SPO-RZL & EFS & $\begin{array}{l}\text { Usługi spo- } \\
\text { leczne }\end{array}$ \\
\hline & 2 & $\begin{array}{l}\text { Budowa kanalizacji sanitarnej } \\
\text { w ul. Kościelnej w Barcinie }\end{array}$ & $306933,3 \mathrm{zl}$ & $59 \%$ & ZPORR & EFRR & Ład ekologiczny \\
\hline & 3 & $\begin{array}{l}\text { Zakup sprzętu RTG i urządzenia do automatycznego wywoly- } \\
\text { wania zdjęć (SPZOZ Barcin) }\end{array}$ & $207460,0 \mathrm{zl}$ & $60 \%$ & ZPORR & EFRR & $\begin{array}{l}\text { Infrastruktura } \\
\text { społeczna }\end{array}$ \\
\hline & 4 & Modernizacja i wyposażenie Wiejskiego Domu Kultury w Mamliczu & $103996,0 \mathrm{zl}$ & $66 \%$ & SPO-ROL & EFOiGR & \\
\hline & \multicolumn{2}{|r|}{ Razem } & $1262406,2 \mathrm{zl}$ & & & & \\
\hline & \multicolumn{2}{|r|}{ Razem per capita } & $84,3 \mathrm{zl}$ & $00 \%$ & & & \\
\hline \multirow[t]{3}{*}{ Gąsawa } & 1 & $\begin{array}{l}\text { Odnowienie boiska sportowego i urządzenie placu zabaw dla } \\
\text { dzieci w Gogólkowie }\end{array}$ & $23117,7 \mathrm{zl}$ & $68 \%$ & SPO-ROL & EFOiGR & $\begin{array}{l}\text { Infrastruktura } \\
\text { społeczna }\end{array}$ \\
\hline & \multicolumn{2}{|r|}{ Razem } & $23117,7 \mathrm{zl}$ & & & & \\
\hline & \multicolumn{2}{|c|}{ Razem per capita } & $4,4 \mathrm{zl}$ & $68 \%$ & & & \\
\hline \multicolumn{3}{|c|}{ Gminy powiatu żnińskiego razem } & $11789448,6 \mathrm{zl}$ & & & & \\
\hline \multicolumn{3}{|c|}{ Gminy powiatu żnińskiego razem per capita } & $166,5 \mathrm{zl}$ & $70 \%$ & & & \\
\hline
\end{tabular}

UŚU - udział środków unijnych; PO - program operacyjny; KZW - kategoria zadań własnych gminy.

Źródło: opracowanie własne na podstawie danych związanych $z$ wykorzystaniem funduszy europejskich w Polsce (http://www.mapadotacji-gov.pl/; dostęp: 8.12.2014). 
Doświadczenie zdobyte w latach 2004-2006 pozwoliło gminom powiatu żnińskiego jeszcze skuteczniej aplikować o środki w ramach funduszy strukturalnych i Funduszu Spójności w kolejnej perspektywie finansowej polityki regionalnej Unii Europejskiej. Co więcej, w okresie 2007-2013 samorządy lokalne realizowały zdecydowanie większe projekty, pochłaniające nieporównywalnie więcej środków finansowych, co przekładało się na wysokość dofinansowania z unijnego budżetu. Całkowita wartość 37 projektów wdrażanych przez wszystkie gminy powiatu żnińskiego $\mathrm{w}$ latach 2007-2013 osiągnęła ponad 64,7 mln zł (914,6 zł per capita), a udział środków europejskich wyniósł 53\% (patrz tab. 3). Ze wsparcia $w$ ramach funduszy unijnych w największym stopniu skorzystała gmina Barcin, która zrealizowała 15 przedsięwzięć wartych 1860,0 zł w przeliczeniu na mieszkańca, pozyskując na ich dofinansowanie 55\% środków. Drugą pod tym względem jednostką samorządu lokalnego w powiecie był Żnin, z liczbą ośmiu projektów o wartości 941,4 zł per capita i dofinansowaniem na poziomie $40 \%$. Kolejna gmina - Janowiec Wielkopolski - wykonała, podobnie jak w pierwszej perspektywie, pięć inwestycji, jednak ich wartość była dwukrotnie wyższa i wynosiła 585,7 zł na osobę, w tym aż 76\% środków stanowiły fundusze unijne. Natomiast Rogowo pod względem liczby zrealizowanych przedsięwzięć okazało się mniej skuteczne aniżeli w pierwszym okresie programowania, jednak biorąc pod uwagę wartość projektów per capita (518,3 zł) i poziom dofinansowania (72\%), stopień wykorzystania środków europejskich przez gminę zwiększył się. Pozostałe dwie jednostki samorządu lokalnego - Łabiszyn i Gąsawa - zdecydowanie odbiegały od reszty zarówno w zakresie liczby wykonanych inwestycji, jak i ich wartości w przeliczeniu na mieszkańca. Gmina Łabiszyn zrealizowała bowiem zaledwie jedno przedsięwzięcie w wysokości 338,4 zł per capita, pozyskując w ramach funduszy strukturalnych $62 \%$ środków. Gmina Gąsawa natomiast wdrożyła trzy projekty warte 281,4 zł na osobę i uzyskała 75 -procentowe wsparcie finansowe z budżetu Unii Europejskiej.

Obok liczby i wartości pozyskanych projektów bardzo istotne jest ich ukierunkowanie, które zostało scharakteryzowane w układzie pięciu kategorii zadań własnych samorządu gminnego, przedstawionych w pierwszej części niniejszego artykułu. W latach 2004-2013 najwięcej środków przeznaczono na przedsięwzięcia $z$ zakresu ładu ekologicznego realizowane w każdej z gmin powiatu żnińskiego z wyjątkiem gminy Gąsawa. Osiem inwestycji wykonanych w ramach tej kategorii zadań stanowiło $43 \%$ wartości wszystkich projektów pozyskanych przez jednostki lokalne w powiecie żnińskim (patrz ryc. 2). Dofinansowanie z budżetu Unii Europejskiej na przedsięwzięcia z zakresu ładu ekologicznego wyniosło 60\%, a cztery inwestycje współfinansowane były ze środków Funduszu Spójności. Zdecydowanie największe projekty w ramach tej kategorii zadań (patrz tab. 4) wykonała gmina Barcin (1015,9 zł per capita, co stanowiło 52\% wartości wszystkich projektów pozyskanych przez gminę). Najwięcej przedsięwzięć realizowanych przez jednostki samorządu lokalnego w powiecie żnińskim dotyczyło jednak infrastruktury technicznej i ładu przestrzennego oraz usług społecznych. W obu kategoriach zadań pozyskano po 19 projektów, ale ich wartość oraz poziom współfinansowania ze środków funduszy europejskich znacznie się różniły. 
Tabela 3. Projekty współfinansowane ze środków funduszy strukturalnych i Funduszu Spójności pozyskane przez gminy powiatu żnińskiego w perspektywie 2007-2013

\begin{tabular}{|c|c|c|c|c|c|c|c|}
\hline Gmina & Lp. & Tytuł projektu & Wartość & UŚU & $\mathrm{PO}$ & Fundusz & KZW \\
\hline \multirow[t]{17}{*}{ Barcin } & 1 & $\begin{array}{l}\text { Uporządkowanie gospodarki ściekowej } \\
\text { w agłomeracji Barcin („WODBAR") }\end{array}$ & $14905882,6 \mathrm{zl}$ & $53 \%$ & PO IiŚ & $\begin{array}{l}\text { Fundusz } \\
\text { Spójności }\end{array}$ & Ład ekołogiczny \\
\hline & 2 & $\begin{array}{l}\text { Modernizacja płacu } 1 \text { Maja i uł. św. Wojciecha wraz z remontem } \\
\text { chodników i odnową mostu }\end{array}$ & 4578011,3 zl & $34 \%$ & RPO WKP & EFRR & \multirow{4}{*}{$\begin{array}{l}\text { Infrastruktura } \\
\text { techniczna i ład } \\
\text { przestrzenny }\end{array}$} \\
\hline & 3 & Budowa traktu spacerowego nad Notecią & $1030581,1 \mathrm{zl}$ & $58 \%$ & RPO WKP & EFRR & \\
\hline & 4 & $\begin{array}{l}\text { Przebudowa drogi gminnej Sadłogoszcz-Piechcin na odcinku } \\
\text { Załesie Barcińskie-Piechcin }\end{array}$ & $856462,6 \mathrm{zl}$ & $50 \%$ & RPO WKP & EFRR & \\
\hline & 5 & Odnowienie Góry św. Wojciecha w Barcinie & $462107,7 \mathrm{zl}$ & $75 \%$ & RPO WKP & EFRR & \\
\hline & 6 & Budowa i przebudowa stanicy żegłarskiej NEPTUN w Barcinie & $1573332,6 \mathrm{zl}$ & $57 \%$ & RPO WKP & EFRR & \multirow{6}{*}{$\begin{array}{l}\text { Infrastruktura } \\
\text { spoleczna }\end{array}$} \\
\hline & 7 & $\begin{array}{l}\text { Przekształcenie systemu ogrzewania w Szkołe Podstawowej } \\
\text { w Mamłiczu wraz z termomodernizacją budynku }\end{array}$ & $1176956,6 \mathrm{zt}$ & $65 \%$ & RPO WKP & EFRR & \\
\hline & 8 & $\begin{array}{l}\text { Termomodernizacja budynków użyteczności pubłicznej w Barci- } \\
\text { nie: Przedszkoła nr 1, Środowiskowego Domu Samopomocy i fiłii } \\
\text { bibłiotecznej }\end{array}$ & $523389,7 \mathrm{zl}$ & $84 \%$ & RPO WKP & EFRR & \\
\hline & 9 & $\begin{array}{l}\text { Wdrożenie zintegrowanego systemu medycznego obejmującego } \\
\text { zarządzanie lekami i elektroniczny obieg dokumentacji medycz- } \\
\text { nej w SPZOZ w Barcinie }\end{array}$ & $322455,0 \mathrm{zl}$ & $75 \%$ & RPO WKP & EFRR & \\
\hline & 10 & $\begin{array}{l}\text { Termomodernizacja i remont wewnątrz obiektu na stadionie } \\
\text { Zagłębia w Piechcinie }\end{array}$ & $283878,8 \mathrm{zl}$ & $74 \%$ & RPO WKP & EFRR & \\
\hline & 11 & $\begin{array}{l}\text { Przekształcenie systemu ogrzewania w przedszkołu w Piechcinie } \\
\text { wraz z termomodernizacją budynku }\end{array}$ & $234650,4 \mathrm{zl}$ & $74 \%$ & RPO WKP & EFRR & \\
\hline & 12 & DROGOWSKAZ NA AKTYWNOŚĆ & $1208268,5 \mathrm{zl}$ & $85 \%$ & PO KL & EFS & \multirow{4}{*}{$\begin{array}{l}\text { Usługi spo- } \\
\text { leczne }\end{array}$} \\
\hline & 13 & Przedszkołaki z barcińskiej paki & $450496,0 \mathrm{zl}$ & $85 \%$ & PO KL & EFS & \\
\hline & 14 & $\begin{array}{l}\text { „Z nauką ścisłą za Pan Brat" } \\
\text { - projekt partnerski }\end{array}$ & $205000,0 \mathrm{zl}$ & $83 \%$ & PO KL & EFS & \\
\hline & 15 & Przyjazny komputer & $42000,0 \mathrm{zl}$ & $85 \%$ & PO KL & EFS & \\
\hline & \multicolumn{2}{|c|}{ Razem } & $27853472,9 \mathrm{zl}$ & \multirow{2}{*}{\multicolumn{2}{|c|}{$55 \%$}} & & \\
\hline & Raze & n per capita & $1860,0 \mathrm{zl}$ & & & & \\
\hline
\end{tabular}




\begin{tabular}{|c|c|c|c|c|c|c|c|}
\hline Gmina & Lp. & Tytuł projektu & Wartość & UŚU & $\mathrm{PO}$ & Fundusz & KZW \\
\hline \multirow[t]{10}{*}{ Żnin } & 1 & $\begin{array}{l}\text { Przebudowa ułic w obszarze starówki miasta Żnina w ramach } \\
\text { rewitałizacji obszaru miejskiego w Żninie }\end{array}$ & $12607373,6 \mathrm{zl}$ & $23 \%$ & RPO WKP & EFRR & \multirow{2}{*}{$\begin{array}{l}\text { Infrastruktura } \\
\text { techniczna i lad } \\
\text { przestrzenny }\end{array}$} \\
\hline & 2 & Przebudowa uł. Fabrycznej w Żninie & $1435418,2 \mathrm{zt}$ & $35 \%$ & RPO WKP & EFRR & \\
\hline & 3 & Ochrona zlewni rzeki Gąsawki - etap II & $4316850,6 \mathrm{zl}$ & $46 \%$ & PO Iiś & $\begin{array}{l}\text { Fundusz } \\
\text { Spójności }\end{array}$ & Ład ekołogiczny \\
\hline & 4 & AKTYWNI, ZINTEGROWANI, SILNIEJSI & $2124733,8 \mathrm{zl}$ & $85 \%$ & PO KL & EFS & \multirow{4}{*}{$\begin{array}{l}\text { Usługi spo- } \\
\text { leczne }\end{array}$} \\
\hline & 5 & Zajęcia pozałekcyjne szansą na sukces & $1034000,0 \mathrm{zl}$ & $85 \%$ & PO KL & EFS & \\
\hline & 6 & DAJMY SOBIE SZANSĘ & $580521,2 \mathrm{zl}$ & $85 \%$ & PO KL & EFS & \\
\hline & 7 & Na dobry początek & $255031,0 \mathrm{zl}$ & $85 \%$ & $\mathrm{PO} \mathrm{KL}$ & EFS & \\
\hline & 8 & $\begin{array}{l}\text { Przebudowa i modernizacja budynku Miejskiego Ośrodka Pomo- } \\
\text { cy Spolecznej w Żninie }\end{array}$ & $705703,6 \mathrm{zl}$ & $64 \%$ & RPO WKP & EFRR & $\begin{array}{l}\text { Infrastruktura } \\
\text { spoleczna }\end{array}$ \\
\hline & \multicolumn{2}{|r|}{ Razem } & $23059632,1 \mathrm{zl}$ & \multirow{2}{*}{$40 \%$} & & & \\
\hline & \multicolumn{2}{|c|}{ Razem per capita } & $941,4 \mathrm{zl}$ & & & & \\
\hline \multirow{7}{*}{$\begin{array}{l}\text { Janowiec } \\
\text { Wiełko- } \\
\text { połski }\end{array}$} & 1 & $\begin{array}{l}\text { Rekułtywacja składowisk odpadów w województwie kujawsko- } \\
\text {-pomorskim na cełe przyrodnicze }\end{array}$ & $2691039,2 \mathrm{zl}$ & $85 \%$ & PO IiŚ & $\begin{array}{l}\text { Fundusz } \\
\text { Spójności }\end{array}$ & Ład ekołogiczny \\
\hline & 2 & UWIERZ W SIEBIE - ZACZNIJ OD NOWA & $1186997,7 \mathrm{zl}$ & $85 \%$ & PO KL & EFS & \multirow{2}{*}{$\begin{array}{l}\text { Usługi spo- } \\
\text { leczne }\end{array}$} \\
\hline & 3 & Wiem i potrafię & $137984,0 \mathrm{zl}$ & $85 \%$ & PO KL & EFS & \\
\hline & 4 & $\begin{array}{l}\text { Przebudowa drogi gminnej w miejscowości Zrazim - gmina } \\
\text { Janowiec Wiełkopolski }\end{array}$ & $772188,6 \mathrm{zl}$ & $50 \%$ & RPO WKP & EFRR & \multirow{2}{*}{$\begin{array}{l}\text { Infrastruktura } \\
\text { techniczna i lad } \\
\text { przestrzenny }\end{array}$} \\
\hline & 5 & Przebudowa drogi gminnej - uł. Nowa w Janowcu Wiełkopołskim & $632710,8 \mathrm{zl}$ & $50 \%$ & RPO WKP & EFRR & \\
\hline & \multicolumn{2}{|c|}{ Razem } & $5420920,2 \mathrm{zl}$ & \multirow{2}{*}{$76 \%$} & & & \\
\hline & Razer & n per capita & $585,7 \mathrm{zl}$ & & & & \\
\hline
\end{tabular}




\begin{tabular}{|c|c|c|c|c|c|c|c|}
\hline Gmina & Lp. & Tytuł projektu & Wartość & UŚU & $\mathrm{PO}$ & Fundusz & KZW \\
\hline \multirow[t]{7}{*}{ Rogowo } & 1 & $\begin{array}{l}\text { Rekultywacja składowisk odpadów } \\
\text { w województwie kujawsko-pomorskim } \\
\text { na cele przyrodnicze }\end{array}$ & $1287145,2 \mathrm{zl}$ & $85 \%$ & PO Iis & $\begin{array}{l}\text { Fundusz } \\
\text { Spójności }\end{array}$ & Ład ekologiczny \\
\hline & 2 & PROGRAM AKTYWIZACJI SPOŁECZNEJ W GMINIE ROGOWO & $1023435,4 \mathrm{zl}$ & $85 \%$ & PO KL & EFS & \multirow{2}{*}{$\begin{array}{l}\text { Usługi spo- } \\
\text { łeczne }\end{array}$} \\
\hline & 3 & Gospodynie Wiejskie Zmieniają Wieś & $42225,9 \mathrm{zl}$ & $85 \%$ & PO KL & EFS & \\
\hline & 4 & $\begin{array}{l}\text { Przebudowa dróg gminnych w miejscowości Rogowo w ciągu } \\
\text { ulic: Sportowej, Szkolnej oraz Hokejowej }\end{array}$ & $807663,3 \mathrm{zl}$ & $50 \%$ & RPO WKP & EFRR & \multirow{2}{*}{$\begin{array}{l}\text { Infrastruktura } \\
\text { techniczna i ład } \\
\text { przestrzenny }\end{array}$} \\
\hline & 5 & $\begin{array}{l}\text { Przebudowa drogi gminnej w ciągu ulic: } \\
21 \text { Stycznia i Krótkiej w Rogowie }\end{array}$ & $431838,7 \mathrm{zl}$ & $42 \%$ & RPO WKP & EFRR & \\
\hline & \multicolumn{2}{|r|}{ Razem } & $3592308,5 \mathrm{zl}$ & \multirow{2}{*}{$72 \%$} & & & \\
\hline & \multicolumn{2}{|c|}{ Razem per capita } & $518,3 \mathrm{zl}$ & & & & \\
\hline \multirow[t]{3}{*}{ Łabiszyn } & 1 & $\begin{array}{l}\text { Kanalizacja sanitarna osiedla Nowy Rynek I i Nowy Rynek II } \\
\text { w Łabiszynie }\end{array}$ & $3340166,7 \mathrm{zl}$ & $62 \%$ & RPO WKP & EFRR & Ład ekologiczny \\
\hline & Raze & & $3340166,7 \mathrm{zl}$ & \multirow{2}{*}{$62 \%$} & & & \\
\hline & Raze & n per capita & $338,4 \mathrm{zl}$ & & & & \\
\hline \multirow[t]{5}{*}{ Gąsawa } & 1 & AKTYWNA INTEGRACJA W GMINIE GĄSAWA & $920495,8 \mathrm{zl}$ & $85 \%$ & PO KL & EFS & \multirow{2}{*}{$\begin{array}{l}\text { Usługi spo- } \\
\text { łeczne }\end{array}$} \\
\hline & 2 & Równe szanse Gimnazjum w Gąsawie & $181208,4 \mathrm{zl}$ & $85 \%$ & PO KL & EFS & \\
\hline & 3 & $\begin{array}{l}\text { Przebudowa dróg gminnych w Gąsawie w obrębie ulic: Rynek, } \\
\text { Jeziorna i Półwiejska }\end{array}$ & $379716,6 \mathrm{zl}$ & $46 \%$ & RPO WKP & EFRR & $\begin{array}{l}\text { Infrastruktura } \\
\text { techniczna i ład } \\
\text { przestrzenny }\end{array}$ \\
\hline & \multicolumn{2}{|c|}{ Razem } & $1481420,8 \mathrm{zl}$ & \multirow{2}{*}{$75 \%$} & & & \\
\hline & \multicolumn{2}{|c|}{ Razem per capita } & $281,4 \mathrm{zl}$ & & & & \\
\hline \multicolumn{3}{|c|}{ Gminy powiatu żnińskiego razem } & $64747921,1 \mathrm{zl}$ & \multirow{2}{*}{$53 \%$} & & & \\
\hline \multicolumn{3}{|c|}{ Gminy powiatu żnińskiego razem per capita } & $914,6 \mathrm{zl}$ & & & & \\
\hline
\end{tabular}

UŚU - udział środków unijnych; PO - program operacyjny; KZW - kategoria zadań wlasnych gminy.

Źródło: opracowanie wlasne na podstawie danych związanych z wykorzystaniem funduszy europejskich w Polsce (http://www.mapadotacji-gov.pl/; dostęp: 8.12.2014). 


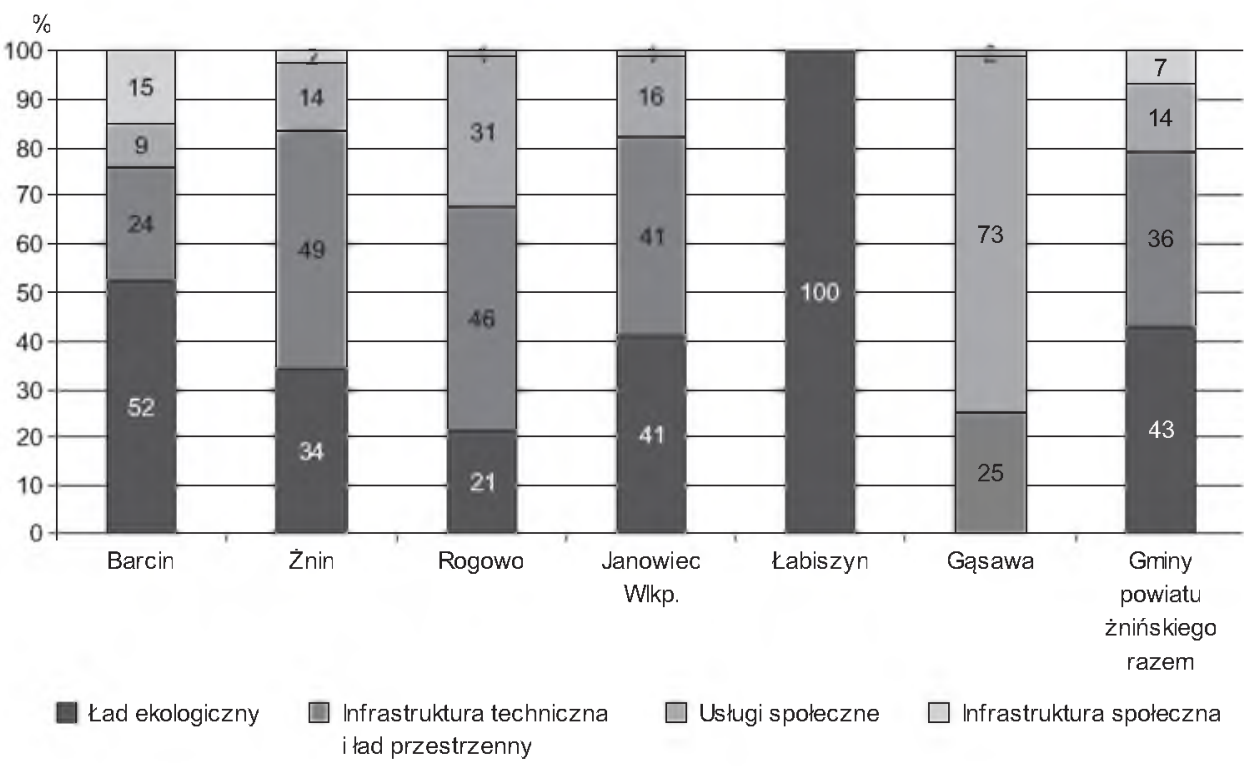

Ryc. 2. Wartość projektów współfinansowanych ze środków funduszy strukturalnych i Funduszu Spójności pozyskanych przez gminy powiatu żnińskiego w latach 2004$2013 \mathrm{w}$ podziale na kategorie zadań własnych samorządu lokalnego

Źródlo: opracowanie wlasne na podstawie danych związanych z wykorzystaniem Funduszy Europejskich w Polsce (http://www-mapadotacji-gov-pl/; dostęp: 8.12.2014)

Inwestycje w zakresie pierwszej kategorii stanowiły $36 \%$ wartości wszystkich pozyskanych przez gminy powiatu żnińskiego projektów (patrz ryc. 2), lecz poziom dofinansowania tych inwestycji z budżetu Unii Europejskiej był bardzo niski i wy-

Tabela 4. Wartość per capita projektów współfinansowanych ze środków funduszy strukturalnych i Funduszu Spójności pozyskanych przez gminy powiatu żnińskiego w latach 2004-2013 w układzie kategorii zadań własnych samorządu gminnego

\begin{tabular}{|c|c|c|c|c|c|c|c|c|}
\hline & & Barcin & Żnin & $\begin{array}{l}\text { Rogo- } \\
\text { wo }\end{array}$ & $\begin{array}{l}\text { Jano- } \\
\text { wiec } \\
\text { Wlkp. }\end{array}$ & $\begin{array}{l}\text { Łabi- } \\
\text { szyn }\end{array}$ & Gąsawa & $\begin{array}{c}\text { Gminy } \\
\text { powiatu } \\
\text { żnińskiego } \\
\text { razem }\end{array}$ \\
\hline & & \multicolumn{7}{|c|}{ zł } \\
\hline \multirow{4}{*}{ 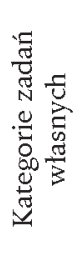 } & Ład ekologiczny & 1015,9 & 398,2 & 185,7 & 359,5 & 338,4 & 0,0 & 465,0 \\
\hline & $\begin{array}{l}\text { Infrastruktura techniczna } \\
\text { i lad przestrzenny }\end{array}$ & 462,6 & 573,3 & 402,9 & 355,9 & 0,0 & 72,1 & 387,6 \\
\hline & Usługi społeczne & 170,3 & 163,1 & 273,8 & 143,1 & 0,0 & 209,3 & 153,5 \\
\hline & Infrastruktura spoleczna & 295,6 & 28,8 & 9,9 & 9,6 & 0,0 & 4,4 & 75,0 \\
\hline \multicolumn{2}{|c|}{ Razem } & 1944,3 & 1163,3 & 872,3 & 868,1 & 338,4 & 285,8 & 1081,2 \\
\hline
\end{tabular}

Źródlo: opracowanie wlasne na podstawie danych związanych z wykorzystaniem Funduszy Europejskich w Polsce (http://www.mapadotacji.gov.pl/; dostęp: 8.12.2014). 
nosił jedynie 37\%. Natomiast przedsięwzięcia z zakresu usług społecznych osiągnęły równowartość $14 \%$ środków przeznaczonych na realizację wszystkich projektów, jednak w tym przypadku wsparcie w ramach polityki regionalnej wyniosło aż 83\%. Największym stopniem wykorzystania środków europejskich w realizacji zadań z zakresu infrastruktury technicznej i ładu przestrzennego wykazała się gmina Żnin (patrz tab. 4), uzyskując najwyższą wartość wykonanych inwestycji (573,3 zł per capita) oraz największy ich udział w całkowitej wartości pozyskanych projektów (49\%). Natomiast pod względem przedsięwzięć społecznych dominowała gmina Rogowo, w której sześć zrealizowanych w tym zakresie projektów wartych było 273,8 zł na osobę, co stanowiło $31 \%$ środków przeznaczonych na wykonanie wszystkich 15 inwestycji gminy z udziałem unijnego dofinansowania. Pozostałych 12 projektów pozyskanych przez samorządy lokalne powiatu żnińskiego dotyczyło infrastruktury społecznej. Na działania związane z tym zakresem interwencji przeznaczono 7\% środków służących realizacji wszystkich unijnych projektów, natomiast wkład funduszy strukturalnych wyniósł $66 \%$. Największym stopniem wykorzystania środków europejskich w tej kategorii zadań wykazała się gmina Barcin, która wykonała w ramach infrastruktury społecznej aż osiem inwestycji wartych 295,6 zł per capita (patrz tab. 4), co stanowiło 15\% wartości wszystkich zrealizowanych przez tę jednostkę przedsięwzięć (patrz ryc. 2). Tym samym w latach 2004-2013 na obszarze gmin powiatu żnińskiego wsparciem ze środków polityki regionalnej Unii Europejskiej nie zostały objęte zadania z zakresu porządku i bezpieczeństwa publicznego.

\section{Podsumowanie}

Analiza gmin powiatu żnińskiego w zakresie stopnia wykorzystania środków funduszy strukturalnych i Funduszu Spójności w realizacji zadań własnych pozwoliła na zaklasyfikowanie badanych jednostek samorządu lokalnego do trzech grup, w zależności od poziomu korzystania ze wsparcia w ramach polityki regionalnej Unii Europejskiej w latach 2004-2013.

Do pierwszej grupy zaliczono gminy Barcin i Żnin, które w największym stopniu skorzystały z możliwości pozyskania środków europejskich na realizację zadań własnych. Potwierdza to zarówno liczba, jak i wartość per capita wdrażanych projektów unijnych. Co więcej, zrealizowane w gminach Barcin i Żnin inwestycje wspólfinansowane ze środków funduszy strukturalnych i Funduszu Spójności stanowiły odpowiednio $42 \%$ i $39 \%$ wartości wydatków inwestycyjnych tych jednostek w latach 2004-2013. Gminy te są dobrym przykładem na to, jak istotne znaczenie $\mathrm{w}$ procesie pozyskiwania pomocy finansowej ma odpowiednie przygotowanie organizacyjne. W pierwszej perspektywie bowiem jednostki te zrealizowały zaledwie 11,1-21,1\% całkowitej liczby projektów. Pozostała część inwestycji została wykonana w kolejnym okresie programowania, a wzrost stopnia wykorzystania środków europejskich przez gminy Barcin i Żnin w latach 2007-2013 pokrywa się ze zmianą struktury organizacyjnej urzędów tych gmin, polegającą na powołaniu nowych komórek organizacyjnych i stanowisk ds. funduszy europejskich. 
Drugą grupę stanowią gminy Rogowo i Janowiec Wielkopolski, które w równie wysokim stopniu korzystały ze środków europejskich, biorąc pod uwagę liczbę pozyskanych projektów. Jednak pod względem wartości per capita zrealizowanych inwestycji znacznie odbiegały one od gmin zaliczonych do pierwszej grupy. Z tego względu Rogowo i Janowiec Wielkopolski można uznać za jednostki odznaczające się przeciętnym poziomem wykorzystania instrumentów finansowych polityki spójności, czego potwierdzeniem jest udział pozyskanych projektów unijnych w wydatkach inwestycyjnych, wynoszący w okresie analizy 26-27\%.

Ostatnią, trzecią, grupę stanowią gminy Łabiszyn i Gąsawa, które zdecydowanie odbiegają od pozostałych jednostek w powiecie pod względem stopnia korzystania ze wsparcia z budżetu Unii Europejskiej. Z uwagi na bardzo małą liczbę oraz wartość zrealizowanych projektów fundusze strukturalne i Fundusz Spójności nie mają istotnego wpływu na finansowanie wydatków inwestycyjnych w tych gminach (w gminie Łabiszyn wspomniane fundusze obejmowały 16\%, a w Gąsawie zaledwie $6 \%$ wydatków inwestycyjnych), a przyczyną takiego stanu rzeczy mogą być trudności z zapewnieniem wymaganego wkładu własnego na realizację projektów, jak również niewłaściwe przygotowanie organizacyjne urzędów gmin.

Analiza kierunków interwencji środków funduszy strukturalnych i Funduszu Spójności wykazała, że samorządy gmin powiatu żnińskiego w pierwszej kolejności realizowały inwestycje związane z najpilniejszymi potrzebami mieszkańców, zwłaszcza w zakresie wyposażenia obszaru gmin w infrastrukturę kanalizacyjna, a także poprawy jakości i dostępności dróg lokalnych. Z tego względu w latach 2004-2013 najbardziej wspieranymi kategoriami zadań własnych okazały się ład ekologiczny oraz infrastruktura techniczna i ład przestrzenny. Na wykonanie projektów w tym zakresie gminy powiatu żnińskiego przeznaczyły aż 79\% środków służących realizacji wszystkich inwestycji z udziałem funduszy europejskich. Należy podkreślić, że zadania własne związane z infrastrukturą techniczną i ochroną środowiska należą do najbardziej kapitałochłonnych i bez pomocy finansowej z budżetu unijnej polityki regionalnej ich realizacja byłaby trudna, szczególnie na tak szeroką skalę. Nieco niższymi udziałami charakteryzują się przedsięwzięcia społeczne. Na uwagę zasługuje jednak wzrost liczby projektów „miękkich” w perspektywie 2007-2013 w porównaniu z wcześniejszym okresem programowania. Najmniej istotnym obszarem interwencji okazała się natomiast infrastruktura społeczna, a jedyny wyjątek w tym względzie stanowiła gmina Barcin.

\section{Literatura}

Borodo A. 2012. Samorząd terytorialny. System prawnofinansowy. LexisNexis, Warszawa.

Churski P. 2008. Czynniki rozwoju regionalnego i polityka regionalna w Polsce w okresie integracji z Unią Europejską. Wydawnictwo Naukowe UAM, Poznań.

Churski P. 2014. Wpływ funduszy Unii Europejskiej na rozwój Poznania na tle wybranych miast w Polsce - próba bilansu pierwszej dekady członkostwa w Unii Europejskiej. [W:] P. Churski, T. Stryjakiewicz (red.), Poznań - próba bilansu przemian w okresie 10 lat członkostwa w Unii Europejskiej, Rozwój Regionalny i Polityka Regionalna, 27: 25-44.

Izdebski H. 2011. Samorząd terytorialny. Podstawy ustroju i dzialalności. LexisNexis, Warszawa. 
Leoński Z. 2006. Samorząd terytorialny w RP. Wydawnictwo C.H. Beck, Warszawa.

Ładysz J. 2008. Polityka strukturalna Polski i Unii Europejskiej. Polskie Wydawnictwo Ekonomiczne, Warszawa.

Niewiadomski Z. 1998. Zadania samorządu terytorialnego na przykładzie planowania przestrzennego. [W:] Z. Niewiadomski, A. Piekara (red.), Samorząd terytorialny. Zagadnienia prawne i administracyjne. Wydawnictwo Prawnicze, Warszawa, s. 293-330.

Rozporządzenie Rady (WE) nr 1083/2006 z dnia 11 lipca 2006 r. ustanawiające przepisy ogólne dotyczące Europejskiego Funduszu Rozwoju Regionalnego, Europejskiego Funduszu Społecznego oraz Funduszu Spójności i uchylające rozporządzenie (WE) nr 1260/1999 (Dziennik Urzędowy Unii Europejskiej, L 210, 31.7.2006, wersja skonsolidowana).

System oceny projektów w ramach Regionalnego Programu Operacyjnego Województwa Kujawsko-Pomorskiego na lata 2007-2013. Wersja nr 5. Toruń, styczeń 2010 (zalącznik do uchwały nr 2/8/10 Zarządu Województwa Kujawsko-Pomorskiego z dnia 7 stycznia 2010 r.).

Tetera M. 2001. Zadania samorządu terytorialnego oraz materialne podstawy i prawne formy realizacji. [W:] Z. Niewiadomski (red.), Samorząd terytorialny. Ustrój i gospodarka. Oficyna Wydawnicza Branta, Bydgoszcz-Warszawa, s. 53-88.

Ustawa z dnia 8 marca 1990 r. o samorządzie gminnym (tj. Dz.U. z 2013 r. poz. 594 z późn. zm.).

Ustawa z dnia 6 grudnia 2006 r. o zasadach prowadzenia polityki rozwoju (t.j. Dz.U. z 2009 r. nr 84, poz. 712 z późn. zm.)

\title{
The diversification of exploiting the Structural Funds and the Cohesion Fund by the Żnin county communes in implementation of their public services in 2004-2013
}

\begin{abstract}
The integration with the European Union has enabled Poland to advance its socio-economic development. The Structural Funds as well as the Cohesion Fund have become the most important determinant of this process. The aim of the article is to investigate the extent to which Żnin county communes benefited from the above mentioned funds for implementation of public services imposed on the local government. The spatial scope of the analysis embraces the communes of the Żnin county while the temporal scope of the research covers the years 2004-2006 and 2007-2013 and coincides with two regional policy frameworks which have been accessible to Poland as a member of the European Union. Since the second financial perspective in which Poland has participated in the European Union is coming to an end, this article is a significant opportunity to sum up hitherto prevailing results of Żnin county communes benefiting from the Structural Funds.
\end{abstract}

Key words: cohesion policy, the EU funds, public services, local government 